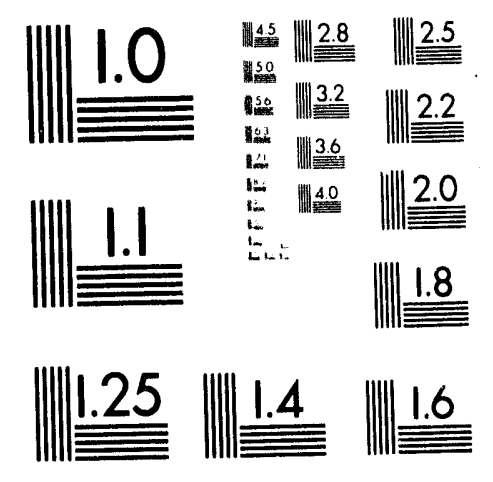



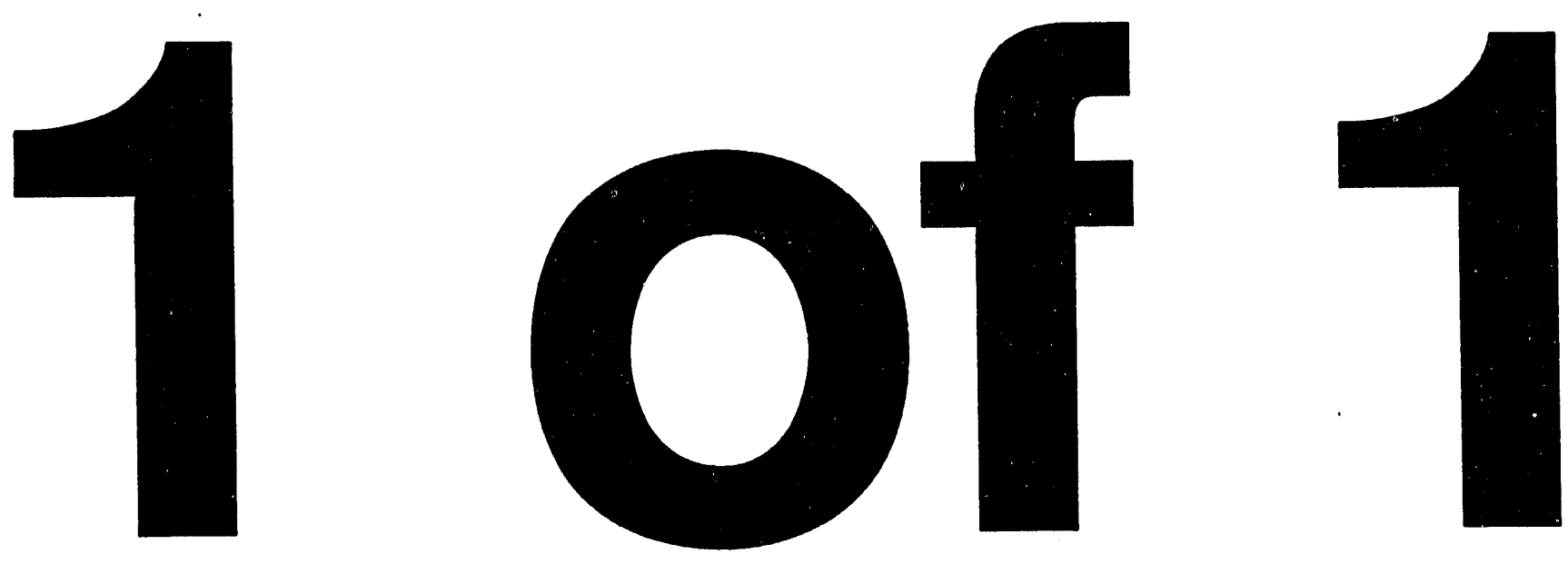


\section{Mixed Waste Solidification Testing on Polymer and Cement-Based Waste Forms in Support of Hanford's WRAP 2A Facility}

D. A. Burbank

K. M. Weingardt

Date Published

October 1993

To be presented at ASTM Symposium Williamsburg, Virginia November $1-5,1993$

Prepared for the U.S. Department of Energy Office of Environmental Restoration and Waste Management

\section{(29) Westinghouse Hanford Company Richland, Washington 99352}

Hanford Operations and Engineering Contractor for the U.S. Department of Energy under Contract DE-AC06-87RL10930

Copyright License By acceptance of this article, the publisher andiar recipient acknowledges the U.S. Government's right to retain a nonexclusive, royalty.tree license in and to any copyright covering this paper. 
Dewey A. Burbank, Jr.' and Kent M. Weingardt'

MIXED WASTE SOLIDIFICATION TESTING ON POLYMER AND CEMENT-BASED WASTE FORMS IN SUPPORT OF HANFORD'S WRAP 2A FACILITY

REFERENCE: Burbank, D. A., Jr., and Weingardt, K. M., "Mixed Waste Solidification Testing on Polymer and Cement-Based Waste Forms in Support of Hanford's WRAP 2A Eacility," American Society for Testing and Materials, 1993.

ABsTRACT: A testing program has been conducted by the Westinghouse Hanford Company to confirm the baseline waste form selection for use in Waste Receiving and Processing (WRAP) Module 2A. WRAP Module 2A will provide treatment required to properly dispose of containerized contacthandled, mixed low-level waste at the U.S. Department of Energy Hanford site in south-central. Washington state. Solidification/stabilization has been chosen as the appropriate treatment for this waste. This work is intended to test cement-based, thermosetting polymer, and thermoplastic polymer solidification media to gubstantiate the technology approach for WRAP Module $2 A$.

Screening testa were performed using the major chemical constituent of each waste type to measure the gross compatibility with the immobilization media and to determine formulations for more detailed testing. Surrogate materials representing each of the eight waste types were prepared in the laboratory. These surrogates were then solidified with the selected immobilization media and subjected to a battery of standard performance tests. Detailed discussion of the laboratory work and results are contained in this report.

KEYWORDS: immobilization, stabilization, polymer, cement, grout, polyethylene

\section{INTRODUCTION}

A testing program has been conducted by Westinghouse Hanford Company (WHC) to confirm the baseline waste form selection for use in Waste Receiving and Processing (WRAP) Module 2A. WRAP Module 2A will provide treatment required to properly dispose of contact-handled (CH), mixed low-level waste (MLLW) accumulating at the U.S. Department of Energy (DOE) Hanford site in south-central Washington state. Solidification/stabilization has been chosen as the appropriate treatment for this waste.

The testing used a phased approach consisting of first screening the compatibility of gurrogate wastes with the immobilization media and then performing detailed physical and chemical tests on laboratoryprepared surrogate waste forms. This will be followed by testing of surrogate waste form specimens prepared by full-scale mixing equipment.

'Engineer, Westinghouse Hanford Company, Richland, Washington 99352. 
The focus of this first phase of test work is to verify the ability of the conceptual design identified immobilization media to adequately solidify those waste types proposed as feed to WRAP Module 2A [1]. Two matrices for waste solidification have been selected: cementbased materials and thermosetting polymer resins. Thermoplastic polymer (specifically low-density polyethylene) was also investigated due to some perceived advantages over the thrrmosetting system. Eight different waste types were used for these initial phases of testing. Four of the waste types were tested with grout waste forms, and four waste types were tested with the thermosetting and thermoplastic polymers.

Test criteria for solidified mixed waste were assembled from applicable regulatory documentation $[2,3,4]$, including guidance documents from the U.S. Nuclear Regulatory Commisgion [ $\underline{5}$ ] and the Environmental Protection Agency [ 6 ]

screening tests were performed using the major chemical constituent of each waste type to measure the gross compatibility with the immobilization media. The results of these testa were positive and are discussed later in the report.

Surrogate wastes were then prepared by WHC to represent each of the eight waste types for testing. Surrogates for thermosetting polymer testing were sent to a vendor commissioned for that portion of the test work. Surrogates for the grout testing were used in the WHC laboratory responsible for the grout performance testing. Solidified test specimens were prepared for both the grout and thermosetting polymer waste forms with the surrogate wastes, and tests were performed. Detailed discussion of the laboratory work and results are contained in this report. All grout specimens performed as expected and confirmed baseline process selection. Test results from the thermosetting polymer demonstrated that an adequate product could be made that passed all acceptance criteria. Some negative results were encountered on the leachability of some hazardous constituents (chrome at high waste loadings and mercury). The thermosetting polymer tests also indicated that leaching results for hazardous constituents, as tested by the toxic characteristic leach procedure (TCLP) method, are very dependant on the sample preparation method.

The polyethylene specimens were able to pass TCLP for all heavy metals except mercury in one of the surrogates. It is anticipated that the leaching of higher mercury concentrations in any stabilization media would need to be controlled with the addition of specific mercury stabilizing chemicals.

\section{WASTE TYPES DESCRIPTION AND WASTE FORM SELECTION} follows.

A general description of the feedstreams chosen for this test work

\section{Liquid Effluent Treatment Facility Secondary Solids}

Two liquid effluent treatment facilities are planned for construction at the Hanford site. The C-018 Facility and the L-045 Facility will produce several secondary waste streams that may be botin radiologically and chemically hazardous. The following are two major waste streams from these facilities.

Ammonium sulfate--The major secondary waste from the $\mathrm{C}-018$ process will be an ammonium sulfate cake produced in an evaporative crystallization process using a thin film evaporator. The high ammonia content of the treatment waste water and the addition of sulfuric acid in the c-018 process led to the formation of ammonium sulfate. This 
waste stream will be generally greater than 90 wto ammonium sulfate with trace regulated contaminants such as chromium and mercury. The waste will be dried before shipment out of the C-018 Facility.

Metal gludge--The L-045 Facility will use a co-precipitation process to remove dissolved contaminants. An iron hydroxide is the baseline precipitation agent in the process. The precipitates are assumed to include various soluble metal contaminants that will be regulated. The sludge will be filtered and possibly dried before shipment from the L-045 Facility.

\section{$183 \mathrm{H}$ Solar Basin Waste}

The 183H Solar Evaporation Basins were used to reduce waste by natural evaporation of liquid chemical wastes generated as part of reactor fuel fabrication activities. The liquid waste discharged to the four concrete basins consisted primarily of spent acid etch solutions (sulfuric, nitric, hydrofluoric, and chromic acids). This waste was generally neutralized with godium hydroxide before discharge to the basins. The wastes contained various metallic contaminants. several types of nonroutine wastes were also discharged to the basins. The basins eventually ceased accepting waste and subsequently were found to have failed and leaked. A timely cleanup and closure of the basins was then pursued. The following waste streams from this cleanup were included in this testing program.

$183 \mathrm{H}$ Crystalline solid--The evaporation of the liquid waste also produced a crystalline solid consisting mostly of salts of nitrate, sulfate, fluoride, and sodium. These wastes were removed from the basins and packaged in poly-lined 208-L (55-gal) drums without further treatment.

\section{$183 \mathrm{H}$ Sludge--The remaining fraction of waste in the $183 \mathrm{H}$ Basins} was a sludge-like material consisting of a mixture of mostly sodium sulfate and sodium nitrate. This fraction was also relatively high in copper content and had more apparent water content than the other wastes (thus its sludge-like consistency). The sludge was packaged in drums with an absorbent material, but had no further treatment.

$183 \mathrm{H}$ Miscellaneous cleanup--After removal of the waste from the basins, contamination remained on the concrete floors and walls. These areas were sandblasted to remove this contamination, resulting in another waste form. Also, cleanup of tumbleweeds and various tools and structures used in the operation were packaged as additional waste.

\section{Ash From Thermal Treatment}

This waste will be produced by the proposed thermal treatment facility for organic mixed waste. The ash residue from this process may need to be treated to account for residual contamination in the waste or to meet treatment standards for mixtures of waste types.

Table 1 shows the specific waste types and selected waste forms. 
WHC-SA-2180-FP

TABLE 1--Treatability testing waste types and waste forms.

\begin{tabular}{|c|c|c|c|c|}
\hline $\begin{array}{l}\text { Test } \\
\text { ID }\end{array}$ & & Title & $\begin{array}{c}\text { Cement-Based } \\
\text { Testing }\end{array}$ & $\begin{array}{l}\text { Polymer } \\
\text { Testing }\end{array}$ \\
\hline Type & 1 & C-018 Ammonium Sulfate & Yes* & Yes \\
\hline Type & 2 & $\begin{array}{l}\text { 183H sludge (Basing \#1 } \\
\text { and \#2) }\end{array}$ & & Yes \\
\hline Type & 3 & $\begin{array}{l}\text { 183H Sludge (Basins \#3 } \\
\text { and \#4) }\end{array}$ & & Yes \\
\hline Type & 4 & 183H Crystalline Solid & & Yes \\
\hline Type & 5 & $\begin{array}{l}\text { 183H Misc. Clean-up } \\
\text { (High Cu) }\end{array}$ & Yes & \\
\hline Type & 6 & $\begin{array}{l}\text { 183H Misc. Clean-up } \\
\text { (High } \mathrm{NO}_{3} \text { ) }\end{array}$ & Yes & \\
\hline Type & 7 & L-045 Metal sludge & Yes & \\
\hline Type & 8 & $\begin{array}{l}\text { Ash from Thermal } \\
\text { Treatment }\end{array}$ & Yes & \\
\hline
\end{tabular}

*Envirostone - A trademark of the American Gypsum Company.

Table 1 shows that several of the feedstreams were split into numerous waste types for testing to group wastes with similar chemical constituents. The first four waste types were chosen for testing with the polymer because of their high soluble salt content (including high nitrate content), which is known to cause problems with cement solidification. Waste types 5 through 8 were chosen for testing with cement waste forms because they do not contain a high content of any constituents that interfere with cement solidification.

Type 1 waste demonstrates a special problem with cement; that is, the ammonium sulfate would react with the high $\mathrm{pH}$ solutions in ordinary portland cement, evolving ammonia gas. Envirostone, ${ }^{2}$ a gypsum-based cement that exhibits a neutral pH, was selected as an alternative to ordinary portland cement for this waste stream.

Surrogate formulas for each of the eight feedstreams were developed and then prepared in the WHC laboratories. Table 2 shows approximate compositions for the surrogates.

\section{Test Selection and Acceptance Criteria}

The main objective of the waste treatability testing is to demonstrate the successful treatment of $\mathrm{CH}$-LLMW feed streams using the technologies proposed for use in WRAP Module 2A. To demonstrate successful treatment, the final waste forms must be subjected to numerous tests to show compliance with all applicable regulatory requirements. Table 3 summarizes the tests that were performed and the performance acceptance criteria. The tests were selected to cover a broad spectrum criteria that could be imposed on the final waste form. The acceptance criteria are composed of a conservative set of tests and requirements that were compiled from several sources including the U.S. Nuclear Regulatory Commission [7], U.S. Environmental Protection Agency $[\underline{3}, \underline{5}, \underline{6}]$, Washington state Department of Ecology [ $\underline{3}]$, and Hanford site specific solid waste acceptance criteria [I].

${ }^{2}$ Envirostone is a trademark of American Gypsum Company. 
WHC-SA-2180-FP

TABLE 2--surrogate wastes approximate composition.

\begin{tabular}{|c|c|c|c|c|c|c|c|}
\hline \multirow{2}{*}{ Component } & \multirow[t]{2}{*}{$\begin{array}{l}\text { Waste } \\
\text { Type } 1 \\
\text { LETF } \\
\text { Salts }\end{array}$} & \multicolumn{2}{|c|}{$\begin{array}{c}\text { Waste } \\
\text { Type } 2 \\
\text { Basins \#1, } \\
\text { \#2 sludge }\end{array}$} & \multicolumn{2}{|c|}{$\begin{array}{c}\text { Waste } \\
\text { Type } 3 \\
\text { Basing \#3, } \\
\text { \#4 sludge }\end{array}$} & \multicolumn{2}{|c|}{$\begin{array}{l}\text { Waste } \\
\text { Type } 4 \\
\text { Basin } \\
\text { Crystal } \\
\text { Solids }\end{array}$} \\
\hline & & & 218 & & 190 & & \\
\hline Barium (ppm) & & & & & 24 & & 100 \\
\hline Beryll ium (ppm) & & & 6 & & 2.3 & & \\
\hline Cadmium (ppm) & & & & & 6 & & \\
\hline Chromium (ppm) & 187.5 & & 900 & & 390 & & 500 \\
\hline Copper (ppm) & 201.0 & 130 & 000 & 112 & 000 & 63 & 000 \\
\hline Mercury (ppm) & 9.2 & & 1.3 & & & & \\
\hline Nickel (ppm) & 46.5 & & 100 & & 130 & & 400 \\
\hline Subtotal (ppm) & 444.20 & 131 & 225.30 & 11. & 742.30 & 64 & 000.00 \\
\hline Ammonium (z) & 22.83 & & & & & & \\
\hline Fluoride (z) & & & 6.0 & & 1.3 & & 7.1 \\
\hline Nitrate (8) & 1.1 & & 13.5 & & 26 & & 1.6 \\
\hline Sodium (z) & & & 20.0 & & 24 & & 22.9 \\
\hline Sulfate (z) & 64.61 & & 20.2 & & 3.7 & & 35.5 \\
\hline Water (8) & 10.0 & & 21.58 & & 25.03 & & 24.5 \\
\hline Subtotal (z) & 98.54 & & 81.28 & & 80.03 & & 91.60 \\
\hline Inerts (z) & 1.42 & & 5.6 & & 8.7 & & 2.0 \\
\hline Total (8) & 100.00 & & 100.00 & & 100.00 & & 100.00 \\
\hline
\end{tabular}

Waste Surrogates for Cement Testing:

Type 5 - 908 Sandblast Grit w/108 Type 2 similar contanination. *

Type 6 - 908 Sandblast Grit $w / 108$ Type 4 similar contamination. *

Type 7 - 98.78 Ferric Oxide Reagent, 1.38 Sodium Sulfide,

$0.7 \%$ Polymer Flock.*

Type 8 - 908 Fly Ash, 8z Clay, 28 Sand.*

* Trace contaminants and concentrations used for cement testing surrogates are detailed later in the report on the table reporting results for solidified product leach testing. 
WHC-SA-2180-FP

TABLE 3--WRAP Module 2A waste form performance specifications.

\begin{tabular}{|c|c|c|}
\hline $\begin{array}{c}\text { Waste Form } \\
\text { Characteristic }\end{array}$ & Test Method & Acceptance Criteria \\
\hline Compressive strength & $\begin{array}{l}\text { ASTM D695 or } \\
\text { ASTM C } 39\end{array}$ & Strength $>500 \mathrm{pei}$ \\
\hline Leachability Index & ANS 16.1 & Leach Index $>6$ \\
\hline Biodegradation & $\begin{array}{l}\text { ASTM G21 and G22, } \\
\text { ASTM D } 695 \text { or } \\
\text { ASTM C } 39\end{array}$ & $\begin{array}{l}\text { No growth, } \\
\text { strength > } 500 \text { pal }\end{array}$ \\
\hline Thermal Cycling & $\begin{array}{l}\text { ASTM B553, } \\
\text { ASTM D } 695 \text { or } \\
\text { ASTM C } 39\end{array}$ & $\begin{array}{l}\text { strength > } 500 \text { pei } \\
\text { after } 30 \text { thermal } \\
\text { cycles }\end{array}$ \\
\hline Radiation stability & $\begin{array}{l}\text { ASTM D } 695 \text { or } \\
\text { ASTM C } 39\end{array}$ & $\begin{array}{l}\text { strength }>500 \text { pei } \\
\text { after irradiation } \\
\text { to } 10^{8} \text { rad }\end{array}$ \\
\hline Immersion & $\begin{array}{l}\text { ASTM D } 695 \text { or } \\
\text { ASTM C } 39\end{array}$ & $\begin{array}{l}\text { strength > } 500 \text { psi } \\
\text { after 90-day water } \\
\text { immersion }\end{array}$ \\
\hline Free Liquids & ANS 55.1 & Free liquid $<0.58$ \\
\hline $\begin{array}{l}\text { Hazardous } \\
\text { Characteristics }\end{array}$ & 40 CFR 261 & $\begin{array}{l}\text { Not ignitible, not } \\
\text { corrosive, not } \\
\text { reactive }\end{array}$ \\
\hline $\begin{array}{l}\text { Toxicity } \\
\text { Characteristics }\end{array}$ & $\begin{array}{ll}\text { EPA } & 1311 \text { (TCLP), } \\
\text { EPA } & 6010\end{array}$ & $\begin{array}{l}\text { TCLP leachable } \\
\text { constituents below } \\
\text { EPA limits* }\end{array}$ \\
\hline
\end{tabular}

NOTE: Multiply psi by 0.07031 to obtain $\mathrm{kg} / \mathrm{cm}^{2}$.

*EPA limits as described in 40 CFR 268.41, Table CCWE.

ASTM = American Society for Testing and Materials

ANS = American Nuclear Society

$E P A=$ U.S. Environmental Protection Agency.

\section{Testing Description and Results}

The waste treatability test work for WRAP Module 2A is using a phased approach. Test work can be broken down into three phases.

Phase 1. Screening tests - screening of waste form compatibility with waste types.

Phase 2. Surrogate performance testing - Detailed testing of waste forms produced on a laboratory scale with surrogate waste.

Phase 3. Full-scale and advanced laboratory studies aimed at developing chemical and physical operating parameters for the selected processes, which is not covered by this report.

Phase 1: Screening tests - cement-based waste forms--The cementbased waste form screening was performed in WHC laboratories to test the raw compatibility of the waste chemicals with cement and to narrow in on the best type of cement formulation, given a specific waste type. Several types of cements and various formulations (waste loadings) were used with each waste type, and setting characteristics were observed. Table 4 lists the selected cement formulations based on these screening tests. 
WHC-SA-2180-FP

TABLE 4--Cement binder formulations from screening teats.

\begin{tabular}{|c|c|c|c|c|c|}
\hline & Type 1 & Type 5 & Type 6 & Type 7 & Type 8 \\
\hline Waste & $\begin{array}{l}\text { Ammonium } \\
\text { sulfate } \\
11.5 \text { wt? }\end{array}$ & $\begin{array}{l}\text { Grit/ } \\
\text { sludge } \\
41.7 \text { wt: }\end{array}$ & $\begin{array}{l}\text { Grit/ } \\
\text { Solids } \\
41.7 \text { wts }\end{array}$ & $\begin{array}{l}\text { Ferric } \\
\text { oxide } \\
15.4 \text { wt } 8\end{array}$ & $\begin{array}{l}\text { Agh mix } \\
30.0 \text { wts }\end{array}$ \\
\hline $\begin{array}{l}\text { Primary } \\
\text { binding } \\
\text { agent }\end{array}$ & $\begin{array}{l}\text { Envirostone } \\
57.5 \text { wts }\end{array}$ & $\begin{array}{l}\text { Type III } \\
41.6 \text { wts }\end{array}$ & $\begin{array}{l}\text { slag } \\
\text { cement } \\
37.5 \text { wtg }\end{array}$ & $\begin{array}{l}\text { Type III } \\
42.6 \text { wts }\end{array}$ & $\begin{array}{l}\text { Slag } \\
\text { cement } \\
40.5 \text { wt } 8\end{array}$ \\
\hline Additive 1 & $\begin{array}{l}\text { Citric acid } \\
1.1 \text { wto }\end{array}$ & - & $\begin{array}{l}\text { Type III } \\
4.2 \text { wt } 8\end{array}$ & - & $\begin{array}{l}\text { Type III } \\
4.5 \text { wto }\end{array}$ \\
\hline Additive 2 & $\begin{array}{l}\text { sodium bicarb. } \\
1.1 \text { wto }\end{array}$ & - & - & - & - \\
\hline Water & 28.7 wto & 16.7 wto & 16.7 wt8 & 38.58 & 25 wto \\
\hline
\end{tabular}

Some special complications were discovered through the fast set characteristics exhibited by the Envirostone when mixed with an ammonium sulfate (Type 1). The set occurred too rapidly to be of use in a typical mechanical mixer. A slow set Envirostone was tried with little or no success; however, the use of citric acid or sodium citrate retarderg were successful.

Phase 1: Screening tests - thermosetting polymer waste form-screening tests for the thermosetting polymer immobilization process were performed at a private vendor's (Diversified Technologies) rented laboratory space at Saginaw Valley state University. Fifteen screening tests were performed using Diversified Technologies vinyl ester polymer immobilization process. The technique was observed by the attenders and videotaped by WHC. The materials that were solidified were intended to represent the major chemical characteristics of the wastes selected for thermosetting polymer testing and some waste samples that the vendor had prepared for demonstration. The materials that were solidified included reagent grade sodium nitrate, ammonium sulfate, and hydrated sodium sulfate (major chemical constituents of waste being treated with polymer). The chemicals were used in both wet and dry form and in combination with diatomaceous earth to simulate both crystalline and sludge-type material.

All specimens gelled within a short period of time (approximately 1 to 10 minutes) and reached full strength and hardness within 30 minutes. The process successfully immobilized sodium nitrate and ammonium sulfate at 60 wto loading with no apparent side reactions. The samples that contained hydrated sodium sulfate crystals exuded some free liquid during the curing exotherm of the polymer (as much as 2 wto). This occurred both with wet and dry waste loadings.

Formulation development tests were then performed by stock Equipment Company to obtain a qualitative measure of waste loading capacity, chemical compatibility, and free water generation. The initial trials were successful for Type 1 and Type 3 surrogates. Additional investigation of Type 2 waste revealed that the pH of the gurrogate did not resemble the actual waste. The pH of Type 2 surrogate was adjusted to 10.5 to more closely resemble the actual waste, and a 
suitable formulation was developed for Type 2 and 4 waste using a different binder material. Table 5 summarizes the formulations that were ueed to prepare the waste form apecimens.

TABLE 5--Polymer formulation parameters.

\begin{tabular}{lcccc}
\hline Formulation parameter & Type 1 & Type 2 & Type 3 & Type 4 \\
\hline Waste/Binder ratio, Kg/Kg & $4 / 2$ & $3 / 3$ & $4 / 2$ & $3 / 2$ \\
Binder type & $A^{*}$ & $B^{*}$ & $A^{*}$ & $B^{*}$ \\
Catalyst dose, wt8 of binder & 2.5 & 7.5 & 2.5 & 5.0 \\
Promoter dose, wt8 of binder & 0.1 & 2.0 & 0.1 & 1.0 \\
Total mixing time, minutes & 25 & 8.5 & 8.5 & 10.5 \\
Peak mixing power, watta & 45 & 12.3 & 9.9 & 13.9 \\
Peak exotherm, degrees C & 38.2 & 70 & 57.5 & 63 \\
Peak exotherm time, minutes & 75 & 30 & 120 & 25 \\
\hline
\end{tabular}

* Note: The use of ' $A$ ' and ' $B$ ' denotes that two different binders were used for this test work to accommodate the waste types.

Phase 2: Surrogate Performance Tegts - Cement-Based Waste Form Results. The cementitious waste forms were prepared by combining the waste gurrogates and the cementitious binders according to the formulations developed during the screening tests. The surrogate material and the cementitious binder were measured into a 18.9-L (5-gal) capacity, heavy duty Hobart variable mixer, where they were mixed until a homogeneous mixture was obtained. A minimum of $9.5 \mathrm{~L}(2.5 \mathrm{gal})$ of cement-waste slurry was required for each set of experiments. For each waste type tested, a cement-waste slurry was prepared in three batches and poured out separately into the appropriate sized molds. Sample molds included $5-\mathrm{cm}$ by $5-\mathrm{cm}(2-i \mathrm{n}$. by $2-i \mathrm{n}$.) cubes, small cylinders $(7.6 \mathrm{~cm}$ [ $3 \mathrm{in.]}$ diameter by $15.2 \mathrm{~cm}$ [ $6 \mathrm{in.]}$ high), and large cylinders $(15.2 \mathrm{~cm}$ [6 in.] diameter by $30.5 \mathrm{~cm}[12 \mathrm{in.]}$ high). The wet specimens were covered with plastic or placed in plastic bags to simulate placement in a 208-L (55-gal) drum or another sealed container. The cube samples were removed from their metal molds after approximately 3 days. The samples were labeled and placed in plastic bags at room temperature until the appropriate cure time was achieved. After curing, the samples were weighed and then tested. The cylinders were kept in their molds and covered until tested. Cement controls (no waste) were made for compression strength reference. Tables 6 and 7 describe the results of the tests. 
WHC-SA-2180-FP

TABLE 6--Cement-based waste form regults.

\begin{tabular}{|c|c|c|c|c|c|c|c|c|c|}
\hline $\begin{array}{l}\text { Waste } \\
\text { Type }\end{array}$ & & $\begin{array}{r}\text { ompreg } \\
\text { streng } \\
\text { (pei }\end{array}$ & $\begin{array}{l}\text { a } 1 v e \\
\text { th* } \\
\text { ) }\end{array}$ & $\begin{array}{l}\text { Radiation } \\
\text { stability }\end{array}$ & Blodegr & radation & $\begin{array}{l}\text { Leach } \\
\text { Index }\end{array}$ & $\begin{array}{c}\text { Water } \\
\text { Immersion } \\
14 / 42 / 90 \\
\text { days }\end{array}$ & $\begin{array}{c}\text { Thermal } \\
\text { Cycle }\end{array}$ \\
\hline Control & 7 & $400 / 4$ & 5110 & - & & - & - & - & - \\
\hline 5 & 7 & $100 / 5$ & 4011 & $\begin{array}{cc}8 & 500 / \\
9 & 100\end{array}$ & 10 & 300 & $\begin{array}{l}12.2 \\
(\mathrm{Ru})\end{array}$ & $\begin{array}{c}8900 / \\
3900 / \\
8400\end{array}$ & $\begin{array}{cc}5 & 500 / \\
8 & 000\end{array}$ \\
\hline 6 & 3 & $500 / 4$ & 200 & $\begin{array}{c}3800 / \\
4800\end{array}$ & 6 & 100 & $\begin{array}{l}12.7 \\
(\mathrm{Co})\end{array}$ & $\begin{array}{cc}5 & 300 / \\
2 & 600 / \\
5 & 500\end{array}$ & $\begin{array}{r}4000 / \\
4400\end{array}$ \\
\hline 7 & 2 & $800 / 2$ & 100 & $\begin{array}{cc}2500 / \\
2000\end{array}$ & 3 & 100 & $\begin{array}{c}9.7 \\
(\mathrm{Na})\end{array}$ & $\begin{array}{cc}2 & 400 / \\
1 & 100 / \\
3 & 000\end{array}$ & $\begin{array}{r}2200 / \\
2400\end{array}$ \\
\hline 8 & 3 & $400 / 2$ & 400 & $\begin{array}{c}4100 / \\
3900\end{array}$ & 4 & 600 & $\begin{array}{l}12.7 \\
\text { (Ru) }\end{array}$ & $2 \begin{array}{c}3900 / \\
500 / 4\end{array}$ & $\begin{array}{c}2900 / \\
3100\end{array}$ \\
\hline 1 & & $<50 / 7$ & & $35 /<50$ & & $>50$ & $\begin{array}{c}9.9 \\
(\mathrm{Ce})\end{array}$ & failed & $>50 / 50$ \\
\hline
\end{tabular}

NOTE: Multiply psi by 0.07031 to obtain $\mathrm{kg} / \mathrm{cm}^{2}$.

* Compressive strength reported for small cylinder/large cylinder per ASTM standarda specified in Performance specifications - large cylinder specific to cement forms.

TABLE 7--TCLP results for WRAP Module 2A cement waste forma.

\begin{tabular}{lllccc}
\hline $\begin{array}{c}\text { Waste } \\
\text { Type }\end{array}$ & Species & $\begin{array}{c}\text { Orig. } \\
\text { Cont. }\end{array}$ & $\begin{array}{c}\text { TCLP } \\
\text { Cont. }\end{array}$ & Limit & Pass/Fail \\
\hline 5 & $\begin{array}{l}\text { Chromium } \\
\text { Copper }\end{array}$ & $\begin{array}{l}50 \mathrm{ppm} \\
1.78\end{array}$ & $\begin{array}{l}0.07 \mathrm{ppm} \\
0.09 \mathrm{ppm}\end{array}$ & $\begin{array}{c}5 \mathrm{ppm} \\
\text { No limit }\end{array}$ & $\begin{array}{l}\text { Pass } \\
\text { NA }\end{array}$ \\
6 & Chromium & $50 \mathrm{ppm}$ & $<0.02 \mathrm{ppm}$ & $5 \mathrm{ppm}$ & Pass \\
7 & Chromium & $100 \mathrm{ppm}$ & $<0.03 \mathrm{ppm}$ & $5.0 \mathrm{ppm}$ & Pass \\
& Mercury & $100 \mathrm{ppm}$ & $<0.1 \mathrm{ppb}$ & $0.2 \mathrm{ppm}$ & Pass \\
8 & Barium & $100 \mathrm{ppm}$ & $0.05 \mathrm{ppm}$ & $100 \mathrm{ppm}$ & Pass \\
& Cadmium & $100 \mathrm{ppm}$ & $<0.01 \mathrm{ppm}$ & $1.0 \mathrm{ppm}$ & Pass \\
& Chromium & $500 \mathrm{ppm}$ & $0.3 \mathrm{ppm}$ & $5.0 \mathrm{ppm}$ & Pass \\
& Lead & $100 \mathrm{ppm}$ & $<0.12 \mathrm{ppm}$ & $5.0 \mathrm{ppm}$ & Pass \\
& Mercury & $100 \mathrm{ppm}$ & $0.5 \mathrm{ppb}$ & $0.2 \mathrm{ppm}$ & Pass \\
& Selenium & $100 \mathrm{ppm}$ & $<0.12 \mathrm{ppm}$ & $1.0 \mathrm{ppm}$ & Pass \\
& Silver & $100 \mathrm{ppm}$ & $<0.02 \mathrm{ppm}$ & $5.0 \mathrm{ppm}$ & Pass \\
& Chromium & $700 \mathrm{ppm}$ & $4.0 \mathrm{ppm}$ & $5.0 \mathrm{ppm}$ & Pass \\
& Mercury & $10 \mathrm{ppm}$ & $0.3 \mathrm{ppb}$ & $0.2 \mathrm{ppm}$ & Pass \\
& Nickel & $50 \mathrm{ppm}$ & $0.25 \mathrm{ppm}$ & No 1 imit & Pass \\
\hline
\end{tabular}

The results indicate that the formulations developed in Phase I were succeseful at immobilizing each of the waste types, with the exception of the ammonium-sulfate waste. The waste forms produced from waste types $5,6,7$, and 8 contained no free watex, exhibited 
compressive etrengthe well above what is required, and pased the TCLP tests. These waste types will be further evaluated for grout proceseing in WRAP Module $2 \mathrm{~A}$.

Phase 2: Surrogate performance tegting - thermogetting nolymer waste form. Polymer waste forms testing was performed at vendor facilities (stock Equipment Company). Solidified test opecimens were prepared from waste surrogates in a batch size of approximately 4.7 L (1.25 gal). A variable speed lab mixer with propelier blades operating at $1800 \mathrm{rpm}$ was used. Each set of upecimens was made from a single batch and poured into cylindrical molds. The tests described above were performed on the specimens. Replicate testa were also performed.

Table 8 summarizes regults of the testing. All gpecimens were successfully imriobilized and exhibited strength and durability characteriatica meeting or exceeding the waste form performance epecificationa. Type 3 eurrogate met all of the performance specifications. Leaching characteristics for all ourrogates met the requirements for low-level waste, but some TCLP constituents of types 1 , 2 , and 4 surrogates exceeded the allowable limita.

The TCLP results prompted additional work to develop formulations that could meet the regulatory limite for chromium and mercury. Additional testing was performed using waste loading of 25 wto. Three methods for preparing the TCLP extraction specimens were investigated. One method involved casting pellets from the mixture so no size reduction was required. The other two methods used larger specimens, which were crushed to meet the gize requirements for TCLP, all material was extracted for one method, and the other method discarded fines less than 1-mm screen size prior to extraction.

Both crushing methods were unable to meet TCLP limits for mercury. The pellet method passed for all TCLP constituents present. The use of reduced waste loadings was successful in decreasing the concentrations of TCLP metals observed in the waste extracts, but the sample preparation method apparently has a larger influence on the final results than waste loading. Further investigation is planned to address these concerns.

Follow on Tegting: Thermoplastic Polymer Waste Form

Although not included in the conceptual design for WRAP Module 2A, polyethylene waste form performance was investigated due to perceived processing advantages over the thermosetting polymer. The approach utilized a heated extruder to melt and $\mathrm{mix}$ the low-deneity polyethylene with the surrogate materials. This follows the approach previously demonstrated in support of Rocky Flats Nitrate Salt waste (으. . Screening tests were not performed due to successful demonstration on aimilar waste types in the Rocky flats program. Physical properties of the waste form was also expected to be similar, therefore, testing has concentrated on the leachability of the heavy metal constituents.

Solidified specimens were prepared using the Rocky Flats laboratory extruder and the same waste surrogates used for thermosetting polymer tests. Calcium oxide was added to the higher waste loading specimens to help control the leachability of some of the heavy metals. TCLP tests were run on strands of the solidified PE/waste mixture that had been cut to meet the $3 / 4$ inch size requirement.

Table 9 presents a summary of all TCLP test data obtained to date for polymer waste forms. Polyethylene results indicate generally better performance than VES for all metals except mercury, where the performance is roughly the same. Calcium oxide does not appear to effect the leachability of mercury. 


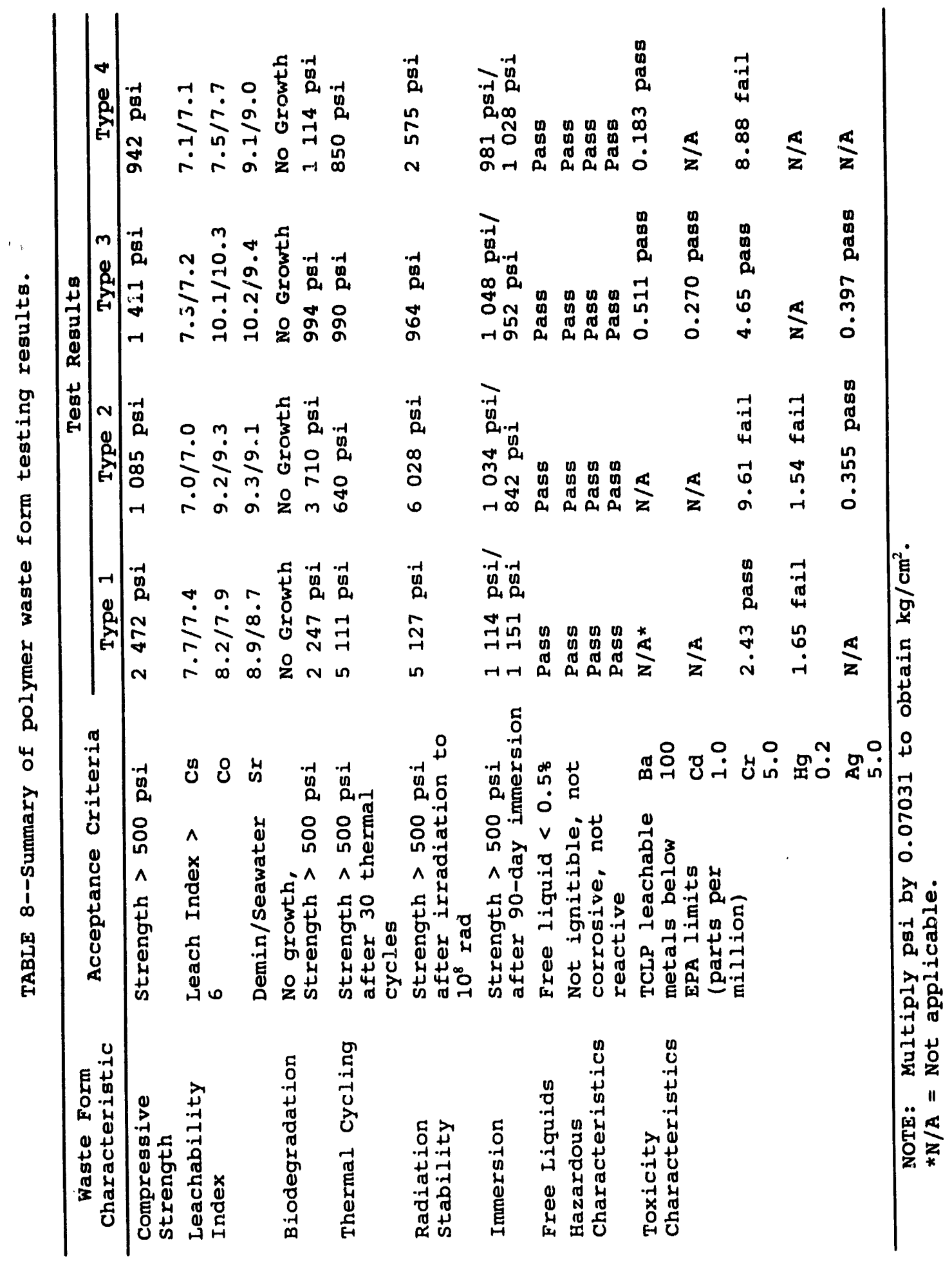


TABLE 9--WRAP 2A polymer testing TCLP resulta.

\begin{tabular}{|c|c|c|c|c|c|c|c|}
\hline \multicolumn{2}{|c|}{ TCLP Regults } & \multicolumn{4}{|c|}{ VES } & \multicolumn{2}{|c|}{$\mathbf{P E}$} \\
\hline \multicolumn{2}{|c|}{ Waste Loading } & 258 & 508 & 608 & 668 & 408 & $508+\mathrm{CaO}$ \\
\hline \multicolumn{2}{|c|}{ Size Red. Method } & pellet & crush & crush & crush & string & string \\
\hline \multirow{2}{*}{$\begin{array}{l}\text { Type } 1 \\
\text { Stream } \\
2 A-1\end{array}$} & $\begin{array}{l}\mathrm{Cr} \\
(5.0)\end{array}$ & $\begin{array}{l}0.275 \\
\text { pass }\end{array}$ & & & $\begin{array}{l}2.43 \\
\text { pass }\end{array}$ & $\begin{array}{l}0.098 \\
\text { pass }\end{array}$ & $\begin{array}{l}0.054 \\
\text { pags }\end{array}$ \\
\hline & $\begin{array}{l}\mathrm{Hg} \\
(0.2)\end{array}$ & $\begin{array}{l}0.182 \\
\text { pass }\end{array}$ & & & $\begin{array}{l}1.65 \\
\text { fail }\end{array}$ & $\begin{array}{l}0.442 \\
\text { fail }\end{array}$ & $\begin{array}{l}1.07 \\
\text { fail }\end{array}$ \\
\hline \multirow{3}{*}{$\begin{array}{l}\text { Type } 2 \\
\text { stream } \\
\text { IC }\end{array}$} & $\begin{array}{l}\mathrm{Ag} \\
(5.0)\end{array}$ & $\begin{array}{l}0.045 \\
\text { pass }\end{array}$ & $\begin{array}{l}0.355 \\
\text { pase }\end{array}$ & & & $\begin{array}{l}<0.010 \\
\text { pass }\end{array}$ & $\begin{array}{l}<0.010 \\
\text { pass }\end{array}$ \\
\hline & $\begin{array}{l}\text { Cr } \\
(5.0)\end{array}$ & $\begin{array}{l}1.76 \\
\text { pass }\end{array}$ & $\begin{array}{l}9.61 \\
\text { fail }\end{array}$ & & & $\begin{array}{l}1.650 \\
\text { paвв }\end{array}$ & $\begin{array}{l}1.770 \\
\text { pass }\end{array}$ \\
\hline & $\begin{array}{l}\mathrm{Hg} \\
(0.2)\end{array}$ & $\begin{array}{l}0.194 \\
\text { pass }\end{array}$ & $\begin{array}{l}1.54 \\
\text { fail }\end{array}$ & & & $\begin{array}{l}0.122 \\
\text { pas8 }\end{array}$ & $\begin{array}{l}0.107 \\
\text { pass }\end{array}$ \\
\hline \multirow{4}{*}{$\begin{array}{l}\text { Type } 3 \\
\text { Stream } \\
\text { 1C }\end{array}$} & $\begin{array}{l}\mathrm{Ag} \\
(5.0)\end{array}$ & & & & $\begin{array}{l}0.397 \\
\text { pass }\end{array}$ & $\begin{array}{l}0.015 \\
\text { pass }\end{array}$ & $\begin{array}{l}<0.010 \\
\text { pass }\end{array}$ \\
\hline & $\begin{array}{l}\mathrm{Ba} \\
(100)\end{array}$ & & & & $\begin{array}{l}0.511 \\
\text { pass }\end{array}$ & $\begin{array}{l}<0.200 \\
\text { pass }\end{array}$ & $\begin{array}{l}<0.200 \\
\text { pass }\end{array}$ \\
\hline & $\begin{array}{l}\text { Cd } \\
(1.0)\end{array}$ & & & & $\begin{array}{l}0.270 \\
\text { pass }\end{array}$ & $\begin{array}{l}<0.005 \\
\text { paøg }\end{array}$ & $\begin{array}{l}<0.005 \\
\text { pasg }\end{array}$ \\
\hline & $\begin{array}{l}\mathrm{Cr} \\
(5.0)\end{array}$ & & & & $\begin{array}{l}4.65 \\
\text { pass }\end{array}$ & $\begin{array}{l}2.740 \\
\text { pass }\end{array}$ & $\begin{array}{l}1.900 \\
\text { pase }\end{array}$ \\
\hline \multirow{2}{*}{$\begin{array}{l}\text { Type } 4 \\
\text { Stream } \\
\text { IB }\end{array}$} & $\begin{array}{l}\mathrm{Ba} \\
(100)\end{array}$ & $\begin{array}{l}0.022 \\
\text { pass }\end{array}$ & & $\begin{array}{l}0.183 \\
\text { pas }\end{array}$ & & $\begin{array}{l}<0.200 \\
\text { pass }\end{array}$ & $\begin{array}{l}<0.200 \\
\text { pass }\end{array}$ \\
\hline & $\begin{array}{l}\mathrm{Cr} \\
(5.0)\end{array}$ & $\begin{array}{l}2.03 \\
\text { pass }\end{array}$ & & $\begin{array}{l}8.88 \\
\text { fail }\end{array}$ & & $\begin{array}{l}0.200 \\
\text { pass }\end{array}$ & $\begin{array}{l}0.450 \\
\text { pas8 }\end{array}$ \\
\hline
\end{tabular}

\section{CONCLUSIONS}

The immobilization/stabilization technologies selected for use in WRAP Module 2A have been tested on waste surrogates reflecting the chemical characteristics of $80 \%$ of the baseline feed volume. The baseline process selection has been confirmed for the feed streams gtudied. Suitable formulations have been developed and waste form performance testing has shown that the technologies are capable of meeting all applicable regulatory acceptance criteria.

Cementitious grout formulas based on type I and type III portland cement, type $\mathbf{S}$ slag cement, or blends of these materials have been developed for four baseline waste streams. Performance test results met or exceeded all waste form performance specifications. Attempts to develop a gypsum-based formulation for the ammonium sulfate waste surrogate were unsuccessful.

Thermosetting polymer formulations have been developed for four additional baseline waste streams. Waste surrogates were successfully immobilized at waste loadings from 50 wto to 66 wto. Performance test results met all specifications except TCLP for chromium and mercury. Specimens prepared with a 25 wto waste loading met TCLP limits for all constituents. TCLP results for polymer waste forms were shown to be highly dependent on the method used for TCLP sample preparation. 
Polyetivlene waste forms have been produced that perform similarly or slightly betzor than VES for the TCLP. In both cases it appears that wastes forms containing higher concentrations of mercury will need to incorporate specific additives to decrease the solubility of mercury under TCLP conditions.

\section{REFERENCES}

[1] UE\&C, WRAP Module 2A Conceptual Design Report, United Engineers and Constructors, Englewood, Colorado, 1992.

[2] NRC, Technical Position on Waste Form, Revision 1, Final Waste Classification and Waste Form Technical Position Papers, U.S. Nuclear Regulatory Commission, Washington, DC, 1991.

[3] EPA, Handbook for stabilization and Solidification of Hazardoug Wastes, U.S. Environmental Protection Agency, Washington, DC, 1984 .

[4] Washington Administrative Code, "Dangerous Waste Regulations," WAC-173-303, Washington state Department of Ecology, Olympia, Washington, 1991.

[5] Code of Federal Requlations, 40 CFR 260-268, office of the Federal Register National Archives and Records Administration, Washington, DC, 1989.

[6] Code of Federal Regulations, 10 CFR 61, Office of the Federal Register National Archives and Records Administration, Washington, DC, 1992.

[7] Willis, N. P., Hanford Site Solid Waste Acceptance Criteria, WHC-EP-0063-3, Westinghouse Hanford Company, Richland, Washington, 1991 .

[8] Tyler, R. W., S. A. Anderson, and T. L. Rising, Land Disposal Restriction (LDR) Waste Management Strategy at Rocky Flats, Proceedings of the Second International Mixed Waste Symposium, A. Alan Moghissi et. al (eds.), Temple University, August 17-20, 1993. 
WHC-SA-2180-FP

\section{DISTRIBUTION}

Number of copies

ONSITE

10

Westinghouse Hanford Company

$\begin{array}{ll}\text { D. A. Burbank } & H 1-60 \\ \text { C. E. McDonald (5) } & \mathrm{G} 6-46 \\ \text { K. M. Weingardt } & \mathrm{H} 1-60 \\ \begin{array}{l}\text { Informat ion Release } \\ \text { Administration }\end{array} & \mathrm{L}-07 \\ \begin{array}{l}\text { Document Processing } \\ \text { and Distribution (2) }\end{array} & \mathrm{L}-15\end{array}$

Distr-1 

$$
-
$$ 